\title{
Covid-19 salgını sürecinde uzaktan eğitimde Türkçe dersine ilişkin sınıf öğretmenlerinin görüşleri
}

\author{
Seyfettin BULUT \\ Fatma SUSAR KIRMIZI ${ }^{\text {b }}$ \\ ${ }^{a}$ Milli Eğitim Bakanlığ1, ORCID:0000-0002-7673-3214 \\ b Pamukkale Üniversitesi, ORCID:0000-0002-0426-1908
}

\begin{abstract}
Özet
COVID-19 salgını süreciyle birlikte zorunlu olarak uzaktan eğitime geçilmiştir. İlkokul öğrencilerinin gelişimsel özellikleri ve okul tecrübeleri düşünüldüğünde uzaktan eğitim sürecinin incelenmesi önem taşımaktadır. Bu çalışmanın amacı sınıf öğretmenlerinin COVID-19 salgını sürecinde uzaktan eğitimde Türkçe dersinde neler yaşadığını ortaya koymaktır. Çalışmada nitel araştırma yöntemlerinden durum deseni tercih edilmiştir. Veriler, araştırmacılar tarafindan oluşturulan dokuz soruluk açık uçlu soru formuyla toplanmıştır. Formlar dijital ortama aktarılarak gönüllü olarak katılmak isteyen ve farklı sınıf kademelerinde görev yapan öğretmenlere ulaştırılmıştır. Yapılan içerik analizi sonucunda araştırmacıların görüş birliği yüzdesi \%80'in üzerinde çıkmıştır. Çalışma sonucunda uzaktan eğitimde kontrol zorluğu, hareketsizlik, eksik katılım, düşük motivasyon sorunları yaşandığı, öğrencilerin konuşmak istemedikleri ve yazma ürünü oluşturamadıkları, teknolojinin aksayan yönlerinin uzaktan eğitime zarar verdiği ortaya çıkmıştır. Ayrıca öğretmenler, firsat eşitliği sağlanarak doğru etkinlik tasarımıyla yapılacak uzaktan eğitimin etkili olacağını ifade etmektedir. Edinilen sonuçlardan yola çıkılarak öğrenme eksiklerinin tamamlanacağı telafi eğitimleri ile dijital yetkinliği ve firsat eşitliğini sağlama çalışmalarının yapılması önerilmektedir.
\end{abstract}

Anahtar Sözcükler: Uzaktan eğitim, türkçe öğretimi, sınıf öğretmeni.

\section{Opinions of classroom teachers on Turkish lesson in distance education during the covid-19 pandemic}

\begin{abstract}
With the COVID-19 outbreak process, compulsory distance education has been introduced. Considering the developmental characteristics and school experiences of primary school students, it is important to examine the distance education process. The aim of this study is to reveal what the primary school teachers experienced in the Turkish lesson in distance education during the COVID-19 epidemic. In the study, the case design, one of the qualitative research methods, was preferred. The data were collected with a nine-question open-ended questionnaire created by the researchers. The forms were transferred to the digital environment and delivered to teachers who wanted to participate voluntarily and who worked at different grade levels. As a result of the content analysis, the consensus percentage of the researchers was over $80 \%$. As a result of the study, it has been revealed that there are difficulties in control, inactivity, incomplete participation, low motivation problems in distance education, students do not want to talk and cannot create writing products, and the disruptive aspects of technology harm distance education. In addition, teachers state that distance education with the right activity design will be effective by providing equal opportunities. Based on the results obtained, it is recommended to carry out compensatory trainings to complete the learning deficiencies and to ensure digital competence and equal opportunity.
\end{abstract}

Keywords: Distance education, turkish teaching, primary school teacher. 


\section{Giriş}

Çeşitli nedenlerden dolayı eğitim öğretim etkinlikleri zaman zaman kesintiye uğrayabilmektedir. Hızla yayılan salgın hastalıklar, yıkıcı depremler, olumsuz hava koşulları gibi nedenler okulların uzun süre kapanmasına neden olabilmektedir. Okulların kapanması eğitim etkinliklerinin aksamasına neden olduğu için bu konuda farklı çözümler üretilmiştir. Uzaktan eğitim, teknolojik gelişmelerin de getirdiği olanaklar kullanılarak yaşamın bir parçası haline gelmiştir. COVID-19 salgını bitse bile uzaktan eğitim olanaklarından vazgeçilmesi pek de olası görülmemektedir (Özgül, Ceran ve Yıldız, 2020). COVID-19 salgınından önce belirli alanlarda sunulan uzaktan eğitim, salgınla birlikte her yaş grubunu, eğitimin her kademesini ilgilendirir olmuştur. Yüz yüze eğitime devam edilmesinin zor olduğu günlere hazırlıklı olmak adına uzaktan eğitim çalışmaları üzerinde bir takım planlar yapılacağı öngörülebilir.

COVID-19 virüsünün bilinmeyen bir zatürre şekline neden olduğu ilk olarak Hubei Eyaletinin başkenti Wuhan'da tespit edilmiştir. Çin, bu durumu 31 Aralık 2019'da Wuhan'daki Dünya Sağlık Örgütü (DSÖ) ofisine rapor halinde bildirmiştir. Aralık 2019'da Çin'de başlayarak tüm dünyaya yayılan ve zamanla dünyayı etkisi altına alan COVID-19 salgını her alanda olduğu gibi eğitim alanında da etkisini göstermiştir. Virüsün yayıldığı ülkeler, eğitimöğretim süreçlerinde insanların birbiri ile temasını en aza indirmek ve hastalığın yayılmasını önlemek amaciyla okulları tatil etmiştir. Nisan 2020'de dünya genelindeki öğrenci nüfusunun \%92'sini oluşturan 188 ülkede eğitime ara verilmiş ve 63 milyondan fazla öğretmen bundan etkilenmiştir (Can, 2020; McAleer, 2020; Özer, 2020). UNICEF (2020a) bu durumu, modern tarihte eğitimde en büyük kitlesel kesinti olarak tanımlamaktadır. Daha sonra ise bireylerin eğitim gereksinimlerinin karşılanması için uzaktan eğitime geçilmiştir. Ülkemizde Mart 2020'de başlayan uzaktan eğitim, süreç içerisinde kademeli olarak okulu açma girişimleri olsa da devamlılık sağlanamamıştır. Ülke çapında alınan kararlar çerçevesinde 2020-2021 eğitim öğretim yılı birinci yarıyılı uzaktan eğitimle tamamlanmıştır. İkinci dönem ise kırsal bölgelerde haftada 5 gün, şehir merkezlerinde 2 gün olmak üzere yüz yüze eğitime geçiş denemeleri olmuştur. Ancak salgının seyri nedeniyle okullar yeniden kapatılmış ve uzaktan eğitime geçilmiştir.

Uzaktan eğitim, bireylerin çeşitli nedenlerle yüz yüze eğitim alamadığı veya aynı ortamlarda bulunamadığı durumlarda yapılan mekândan bağımsız olarak bireysel çalışmanın ön plana çıktığı öğretim şeklidir. Öğrenme sürecinin büyük kısmında öğrenen ve öğreten ayrı ortamlarda bulunmaktadır (Akyürek, 2020). Keskin ve Özer Kaya (2020) uzaktan eğitimi, gelişen bilgisayar ve ağ teknolojilerinin yardımı ile eğitimin öğrencilere web tabanlı bir şekilde 
aktarılması olarak tanımlamaktadır. Uzaktan eğitimin ilk uygulamaları çeşitli nedenlere (coğrafi yapı, uzaklık, sosyo-ekonomik durum vb.) bağlı olarak öğrencilerin ve eğitim kurumlarının bir araya gelememesinden kaynaklanmaktadır. Son yıllarda uzaktan eğitimi avantajlı yapan nedenlerden birisi de bilgi iletişim teknolojilerinin gelişip yaygınlaşması olarak görülmektedir.

Araştırmalar, uzaktan eğitimin dünyada 1700'lü yıllarda başladığını ve 20 Mart 1728 yılında Boston Gazetesi'nde ilan edilen uzaktan eğitimle "Steno Derslerini” ise bir örnek olduğunu ifade etmektedir (Kırık, 2014). Türkiye'de 1924 yılında başlamış, 1982-1983 eğitimöğretim yılında Anadolu Üniversitesi Açık Öğretim Fakültesinin kurulmasıyla fakülte düzeyine yükselmiştir (Karatepe, Küçükgençay ve Peker, 2020; Sarı, 2020). Zaman içerisinde teknolojinin gelişmesi ve yaygınlaşması, öğretim elemanı eksikliği vb. nedenlerle farklı üniversiteler de derslerin bir kısmını uzaktan eğitimle sürdürmeye başlamıştır (Barış, 2015). Bilgi iletişim teknolojileri alanında meydana gelen gelişmeler, uzaktan veya yüz yüze fark etmeksizin eğitim öğretim ortamlarını da etkilemektedir. Jacobs ve Ivone (2020), çevrimiçi öğrenme olanakları sunan modern uzaktan eğitimin, yazışma dersleri diye de adlandırılan ve posta yoluyla yapılan uzaktan eğitimden farklı bir noktada olduğunu vurgulamaktadır. Bilgi iletişim teknolojilerinin gelişimi uzaktan eğitimde büyük değişimlere yol açmakta, öğrenmeöğretme sürecinde büyük dönüşümlerin ortaya çıkmasını sağlamaktadır. Sosyal medya araçları, e-posta, bloglar, çoklu platform, mobil mesajlaşma ve web konferans uygulamaları uzaktan eğitimde en sık kullanılan bilgi iletişim teknolojileri olarak görülmektedir (Martinez, Camacho, Guillen-Gamez ve Agapito, 2020). Türkiye'de temel eğitimde uzaktan eğitim genel olarak çoklu eğitim platformu olan EBA (Eğitim Bilişim A ̆ğı) ve TRT (Türkiye Radyo Televizyon Kurumu) tarafından açılan televizyon kanalları üzerinde kurulmuştur. Teknolojik gelişmeler öğrenene bağımsız çalışma, bireysel hızda ilerleme, web 2.0 araçları ile etkileşimli öğrenebilme olanakları sunmaktadır. Fakat uzaktan eğitimin dijital avantajlarını yakalayabilmek için kişilerin belirli bir bilgisayar donanımı ve alt yapı sahibi olması gerektiği unutmamalidir. 


\section{COVID-19 Salgını Sürecinin Fırsat Eşitliği Üzerindeki Etkisi}

Salgın süreciyle birlikte eğitim öğretim ortamları, dijital araçlarla uzaktan eğitime aktarılmıştır. Fakat eğitim çağındaki her çocuk uzaktan eğitime erişebilecek dijital araçlara veya bunu alabilecek ekonomik olanağa sahip değildir. Eğitim, iş ve istihdam boyutlarıyla değerlendirilen firsat eşitliği sorunu, salgın süreciyle çok önemli bir sorun haline gelmiştir (Kang, 2020). Salgın öncesinde bile pek çok ülkede ilkokul öğrencilerinin okula gidememe nedenlerinden en belirgin olanı yoksulluktur (UNICEF, 2019). Salgınla birlikte öğrenciler arasındaki firsat eşitsizliği daha belirgin bir boyut kazanmıştır.

Uzaktan eğitimin gerektirdiği temel dijital araçlar, alt yapı ve maliyet gibi nedenler eğitim sürecindeki fırsat eşitsizliğini arttırmaktadır. Çin'de yapılan deneysel çalışmalar, uzaktan eğitimin yaygınlaşmasıyla daha az gelişmiş bölgelerdeki eğitim eşitsizliğinin kötüleştiğini göstermektedir (Bouznad ve Ibourk, 2020). UNICEF (2020b), COVID-19 salgını sürecinde sosyo-ekonomik seviyesi düşük bölgelerde yaşayan çocukların uzaktan eğitimden yararlanamamasını iki temel nedene bağlamaktadır. Bunlardan birincisi ebeveynlerin büyük olasılıkla işsiz kalması, ikincisi ise öğrencilerin daha az dijital kaynağa sahip olması olarak açıklanmaktadır. Bu raporlar uzaktan eğitim sürecinin düşük sosyo-ekonomik şartlara sahip çocuklar için firsat eşitliği sağlanamadığını göstermektedir.

Dijital platformlar üzerinden yapılan uzaktan eğitimde öğrencilerin internete erişimi önem taşımaktadır. Fakat dünyada 25 yaş altındaki çocuk ve gençlerin üçte ikisinin (2.2 milyar çocuk) internete erişimi bulunmamaktadır. İnternet erişim oranı yüksek gelirli ailelerde \%87 iken düşük gelirli ailelerde \%6 oranındadır (UNICEF, 2020a). Çünkü internet erişiminin en büyük belirleyicisi ailenin gelir seviyesidir (UNICEF, 2020c). Bu oranlar dünya genelinde uzaktan eğitimdeki firsat eşitsizliğini göstermektedir. Türkiye'de nüfusun demografik yapısı, hemşericilik ve kira fiyatları gibi nedenlerle düşük gelirli ailelerin şehir merkezlerinde kenar mahalleleri tercih ettiği bilinmektedir. Ancak büyük şehirlerin kenar mahalleleri ve köylere internet alt yapısı ile hızı yeterli oranda sağlanamadığı için dijital araçlara sahip olan öğrenciler de çevrimiçi derse girerken sorun yaşamaktadır (Demirören Haber Ajansı, 2020). Bu soruna yönelik olarak MEB (Milli Eğitim Bakanlığı), alt yapısı yeterli olan okullarda EBA sınıfları oluşturarak öğrencilerin derse okulda bağlanmasını sağlamaktadır.

Türkiye'de okulların kapanmasıyla birlikte eğitimin uzaktan eğitim platformlarından devam etmesi planlanmıştır (Özer, 2020). 2019-2020 eğitim öğretim yılının ikinci döneminde ilkokul öğrencileri TRT İlkokul kanalından derslerine devam etmiştir. Oysa uzaktan eğitimde başarı sağlamanın en etkili yollarından birisi yakınlaştırma stratejisi olan öğretmen ve öğrenci 
arasındaki etkileşimi arttırmaktır (Ayda, Baştaş, Altınay, Altınay ve Dağl1, 2020). Bu stratejiye göre öğretmenlerin de kendi aralarında görüşmeler düzenlemesi motivasyonu arttıracaktır. Uzaktan eğitimin teknoloji yardımıyla öğretmen ile öğrenci arasındaki köprüyü oluşturması gerekmektedir (Karatepe, Küçükgençay ve Peker, 2020). Ülkemizde de yapılan değerlendirmeler sonucunda 2020-2021 eğitim-öğretim yılının ilk döneminden itibaren öğrencilerin dersleri TRT İlkokul kanalının yanında öğretmenleriyle mobil öğrenmeyle devam edilmesi kararlaştırılmıştır. Alınan karar gereği dersler, EBA ve diğer uygulamalar üzerinden çevrimiçi olarak yürütülmüştür.

Uzaktan eğitimin; ekonomiklik, erişilebilirlik, geniş kitleye yayılma, zaman ve mekandan bağımsızlık, bireysel öğrenme hız ve yöntemi ile yaşam boyu öğrenmeye uygunluk, cinsiyet eşitliği sağlaması gibi olumlu yönleri bulunmaktadır. Ancak öğrenen ile öğreten etkileşiminin kısıtlı olması, dikkat dağınıklığı, motivasyon eksikliği, belirli bir iletişim alt yapısını gerektirmesi ve teknik sorunların her zaman muhtemel olması gibi dezavantajları da bulunmaktadır (Karakuş, Ucuzsatar, Karacaoğlu, Esendemir ve Bayraktar, 2020). Salgın dönemiyle zorunlu olarak geçilen uzaktan eğitimin etkililiği tartışma konusudur. Çünkü genellikle uzaktan eğitim yüz yüze eğitime bir seçenek olarak görülmektedir (Başar, Arslan, Günsel ve Akpınar, 2019).

Türkçe dersinde konuşma, dinleme, okuma ve yazma becerilerinin uygulamalar içerisinde geliştirilmesi gerekmektedir. Bazı çalışmalar bu beceri alanlarının teknoloji ile desteklenmesi gerektiğini de belirtmektedir(Yaman, 2007). 2000 yılından sonra doğan Z kuşağı teknolojik aygıtlarla bütünleşmeye fazlası ile hazırdır. Teknoloji destekli eğitim öğretim ortamlarında Türkçe dersinin verimliliği artmaktadır (Katrancı ve Uygun, 2013). Teknolojinin sunduğu yenilikler onlar için oldukça ilgi çekicidir Türkçe derslerinde de Z kuşağının bilişim becerilerini geliştirmeye yönelik çalışmalara yer verilmelidir (Altunbay ve Bıçak, 2018; Kavalcı ve Ünal, 2016; Özgül, Ceran ve Yıldız, 2020). COVID-19 salgınında uzaktan eğitimin bu becerilere fazlası ile etki ettiğini söylemek mümkündür. Yalnız COVID-19 salgınına hazırlıksız yakalanılması, eğitim öğretimin bir anda çevrim içine dönüşmesi bu etkinin olumlu yönde olmasına engel olmuştur. Daniel'e (2020) göre eğitim kurumları COVID-19 salgını devam ettiği sürece çevrim içi öğrenmelere devam etmelidir. Ancak salgın sona erdikten sonra öğrencilerin öğrenme kayıplarını gidermek adına esnek yollara ve programlara başvurulmalıdır.

Çevrim içi öğrenmelerde öğrencinin bu öğrenme ortamına ilişkin tutumu büyük bir önem taşımaktadır. Çevrim içi öğrenmelerde öğrencinin dijital yetkinliği ve teknolojik aygıtlara olan 
bakış açısı başarıya ulaşmada oldukça önemli bir boyuttur (Atmojo ve Arif Nugroho, 2020; Gonzalez ve Louis, 2018). Çevrim içi öğrenmenin öğrenciler üzerindeki etkisini araştırmaya yönelik olarak çok sayıda nicel ve nitel araştırma yapılmış olsa da (Gonzalez ve Louis, 2018) COVID-19 salgını sürecinde gerçekleştirilen uzaktan eğitim etkinliklerinin dil öğrenmeye etkisine yönelik çalışmalar oldukça yetersiz olduğunu söylemek mümkündür (Atmojo ve Arif Nugroho, 2020). COVID-19 salgını sürecinde gerçekleştirilen uzaktan eğitim çalışmalarının Türkçe dersinin beceri alanları üzerindeki etkisinin araştırılması kısa sürede pek mümkün görülmemektedir. Bu zaman zarfinda salgın tedbirlerinden dolayı öğretmen, öğrenci ve velilere ulaşmanın zorluğu, yalnızca teknolojik olanaklarla ulaşma sınırlılığı araştırmaların yapılmasında zorlayıcı bir etken olarak öngörülebilir.

Salgın dönemi öncesinde de uzaktan eğitim bir eğitim yöntemi olarak dünyanın her bölgesinde kullanılmaktaydı ancak COVID-19 salgını sürecinden farklı olarak belirli konu içeriklerine göre yürütülmekteydi. Bei, Mavroidis ve Giosos (2019), esnek bir yapıda olan uzaktan eğitimi belirli talepleri karşılamaya yönelik ve öğrenciyi bireysel öğrenmeye motive eden bir eğitim yöntemi olarak ifade etmektedir. Salgın dönemiyle birlikte talep ve konu farkı gözetmeksizin ilkokul öğrencileri tüm derslerini uzaktan eğitimle işlemeye başlamıştır. Oysaki ilkokul öğrencileri, kendi başına öğrenmek yerine çoğu zaman akranlarıyla birlikte öğretmen liderliğinde tartışmalara katılarak ve materyallerle etkileşimli olarak öğrenmek istemektedir (Jacobs ve Ivone, 2020). Üçüncü sınıf öğrencileri üzerinde yapılan bir araştırmada öğrencilerin matematik ve okuma alanındaki yeterliliklerinin okulların açık olmasıyla doğrudan ilişkili olduğu belirlenmiştir (Bouznad ve Ibourk, 2020). Öğrencilerin seviyesi, yaşı ve konu içerikleri de hesaba katıldığında uzaktan eğitim sürecinde çeşitli problemlerin ortaya çıkma olasılığı kaçınılmaz olarak düşünülebilir. Bu problemler eğitim öğretimin paydaşlarından öğrenci, öğretmen, okul yönetimi ve aile boyutlarında yaşanmaktadır. İlkokullarda Türkçe derslerinde uzaktan eğitimde olumlu ve olumsuz olmak üzere farklı durumlar yaşanmıştır. Türkçe dersinde yaşanan bu durumların tespit edilmesi, bilimsel bir bakış açısı ile irdelenmesi öğretmenlerin ve öğrencilerin içinde bulunduğu durumun anlaşılması açısından önemli olabilir. COVID-19 salgını bittikten sonra da uzaktan eğitim, okullara doğrudan ulaşma olanağı olmayan öğrenciler için iyi bir seçenek ve etkin bir yol olarak görülebilir. Yapılan çalışmanın sonuçları ilkokullarda Türkçe derslerinde uzaktan eğitim sürecinin planlanmasında yol gösterici olabilir. UNICEF'in (2020b) COVID-19 salgını sürecinde eğitim ile ilgili hazırlamış olduğu raporda sosyoekonomik düzeyi düşük ailelerin çocuklarının ciddi anlamda firsat eşitliği ilkesinden uzaklaştı̆̆ belirtilmiştir. Yoksul, işçi, işsiz, mevsimlik işçi, mülteci ailelerin çocukları 
ekonomik ve sosyal nedenlerden dolayı eğitim sürecinin dışında kalmıştır. Bu çalışmanın sonuçları Türkiye'de salgın sürecinde fırsat eşitsizliği yaşayan öğrencilerin durumu için de bilimsel veriler sunabilir. Tüm bunlardan yola çıkarak bu çalışmanın amacı "sınıf öğretmenlerinin COVID-19 salgını sürecinde uzaktan eğitimde Türkçe dersinde neler yaşadığını” tespit etmektir. Bu amaca bağlı olarak şu alt problemler belirlenmiştir:

1. Sınıf öğretmenlerinin COVID-19 salgınında, Türkçe öğretiminde "ders işleme sürecinde yaşanan sorunlara" ilişkin görüşleri nelerdir?

2. Sınıf öğretmenlerinin COVID-19 salgınında, Türkçe öğretiminde "beceri alanlarında yaşanan sorunlara" ilişkin görüşleri nelerdir?

3. Sınıf öğretmenlerinin COVID-19 salgınında Türkçe öğretiminde "çevreden kaynaklanan sorunlara" ilişkin görüşleri nelerdir?

4. Sınıf öğretmenlerinin COVID-19 salgınında Türkçe öğretiminde "olması gereken durumlara" ilişkin görüşleri nelerdir?

\section{Yöntem}

$\mathrm{Bu}$ araştırma öğretmenlerin görüşlerini tespit etmeye yönelik olduğu için nitel araştırma yöntemi tercih edilmiştir.

\section{Araştırma Modeli}

Çalışma, nitel araştırma yöntemlerinden durum çalışması temel alınarak gerçekleştirilmiştir. Durum çalışması desenlerinden de "bütüncül tek durum deseni” ile çalışma yürütülmüştür. Durum çalışmaları, güncel bir konuyu etkili olduğu yaşam çerçevesi içinde ve derinlemesine inceleyen, kesin sınırlarının olmadığı, "nasıl”" ve "niçin" sorularını temel alan desendir (Yıldırım ve Şimşek, 2018). Araştırmacılar, çalışma sürecinde sınırlandırılmış durum veya durumlar hakkında çoklu bilgi kaynaklarına başvurarak durumun betimlenmesini sağlamaktadır (Creswell, 2018). Durum çalışmalarının belirgin özelliği, derinlemesine araştırma yapmak ve konuyu bütüncül bakış açısı ile ele almak şeklinde ortaya çıkmaktadır (Yıldırım ve Şimşek, 2018).

\section{Çalışma Grubu}

Bu çalışma, COVID-19 salgınında uzaktan eğitim sürecinin devam ettiği 2020-2021 eğitim öğretim yılı güz yarıyılında, Afyonkarahisar ilinde yapılmıştır. Araştırma, diğer bütün derslerde olduğu gibi Türkçe dersini de uzaktan eğitimle yürüten, farklı sınıf kademelerinde görev yapan ilkokul öğretmenlerinin katılımıyla gerçekleştirilmiştir. 
Çalışma grubunun belirlenmesinde, nitel araştırmalarda sıkça kullanılan amaçlı örnekleme yöntemlerinden "kolay ulaşılabilir durum örneklemesi” tercih edilmiştir. Kolay ulaş1labilir durum örneklemesi; genellikle coğrafi yakınlık, belirli bir zamanda uygulanabilirlik ve katılma isteği gibi nedenlerle veri toplamayı kolaylaştırmaktadır (Etikan, Musa ve Alkassim, 2016). Ayrıca kolay ulaşılabilir durum örneklemesi araştırmaya hız ve pratiklik kazandırmaktadır (Yıldırım ve Şimşek, 2018). Çalışmanın veri toplama sürecinde ise salgın süreci tedbirlerine sıkı sıkıya bağlı kalınmıştır. Öğretmenler, öğrenme öğretme etkinliklerini evlerinden gerçekleştirdiği için araştırma internet ortamında hazırlanan form üzerinden yürütülmüştür. Araştırmaya katılmak isteyen öğretmenler örneklemi oluşturmuştur. Çalışma grubu il, ilçe ve köyde görev yapan öğretmenlerden oluşmaktadır. Araştırma altı farklı okuldan 15 öğretmenle (kadın=8; erkek=7) yürütülmüştür. Öğretmenlerin altısı köy, dördü kasaba, beşi ise şehir merkezinde çalışmaktadır.

\section{Veri Toplama Araçları}

Araştırma verilerinin elde edilmesinde araştırmacılar tarafından geliştirilen açık uçlu soru formu kullanılmıştır. Öncelikle konu ile ilgili olarak yapılan araştırmalar doğrultusunda 12 açık uçlu soru olarak hazırlanmıştır. Oluşturulan sorular uzman görüşü alınması amacıyla alanında uzman iki öğretim elemanı ve iki sınıf öğretmenine sunulmuştur. Uzmanlardan gelen dönütler doğrultusunda işlevsel olmayan üç açık uçlu soru formdan çıkarılmıştır. Ayrıca diğer maddeler de dilbilgisine ve anlatıma yönelik olarak yeniden düzenlenmiştir. Katılımcıların demografik özelliklerini belirlemek amacı ile kişisel bilgiler formu oluşturulmuştur. Kişisel bilgilere yönelik sorular ve araştırmaya yönelik dokuz soru bir araya getirilerek forma son şekli verilmiştir.

\section{Verilerin Toplanması ve Analizi}

Araştırma verilerinin elde edilmesinde COVID-19 salgınına yönelik olarak alınan sağlık tedbirlerine bağlı kalınmıştır. Bu nedenle veriler internet üzerinden öğretmenlere ulaşılarak elde edilmiştir. COVID-19 salgınında, uzaktan eğitim sürecinde sınıf öğretmenlerinin Türkçe dersinde neler yaşadığını belirlemek amacı ile oluşturulan açık uçlu soru formu internet ortamında katılımcıların erişimine sunulmuştur. Araştırmaya katılma konusunda gönüllü olan öğretmenler formu dijital olarak doldurmuştur.

Öğretmenlerin vermiş olduğu yanıtlar nitel veri setini oluşturmaktadır. Verilerin analizi için içerik analizine başvurulmuştur. Katılımcıların verdiği yanıtlar her iki araştırmacı 
tarafından büyük bir duyarlılıkla okunmuş ve araştırmanın kodları belirlenmiştir. Tespit edilen kodlardan ilişkili olanlar bir araya getirilmiş ve temalar ortaya çıkarılmıştır. Tespit edilen kodların tutarlığını tespit etmek amacıyla da Miles ve Huberman'ın görüş birliği formülüne başvurulmuştur. (Güvenirlik Formülü: Görüş Birliği/ Görüş Birliği+Görüş Ayrılı̆̆ı)*100 formülü ile elde edilen görüş birliği yüzdesinin \%80 üzerinde olması istenmektedir (Miles ve Huberman, 1994). Görüş birliği yüzdesi tespiti için yapılan çalışma sonrasında, güvenirlik katsayısı alt problemler için ayrı ayrı hesaplanmıştır. Buna göre güvenirlik formülü sonucu birinci alt problemde 83.76, ikinci alt problemde 82.43, üçüncü alt problemde 86.12 ve dördüncü alt problemde 94.27 olarak hesaplanmıştır. Öğretmenlerin yanıtlarından yola çıkılarak yapılan alıntılar için bir takım kısaltmalar kullanılmıştır. Görüşülen öğretmen sırası (1, 2, 3, 4 vb.); cinsiyeti (Erkek- E, Kadın-K); sınıf düzeyi (1. Sınıf, 2. Sınıf, 3. Sınıf, 4. Sınıf); görev yeri köy, kasaba (Ks.) ve şehir merkezi (Şm.) şeklinde kısaltma yapılarak kullanılmıştır. Araştırma kapsamında oluşturulan kod ve temalar Tablo 1.'de sunulmuştur.

\begin{tabular}{|c|c|c|}
\hline \multicolumn{3}{|l|}{ Tablo 1} \\
\hline \multicolumn{3}{|c|}{$\begin{array}{l}\text { COVID-19 Salgınında, Türkçe Öğretimi Sürecine İlişkin Olarak Oluşturulan Tema ve } \\
\text { Kodlar. }\end{array}$} \\
\hline Tema & Kod & Kod Tekrar \\
\hline \multirow{6}{*}{ Ders Süreci } & Kontrol Zorluğu & 15 \\
\hline & Hareketsizlik & 10 \\
\hline & Düşük Motivasyon & 9 \\
\hline & Dikkat Eksikliği & 9 \\
\hline & Verimliliğin Azalması & 5 \\
\hline & Eksik kat1lım & 2 \\
\hline \multirow{4}{*}{ Beceri Alanları } & Konuşma Sorunu & 14 \\
\hline & Yazma Sorunu & 13 \\
\hline & Okuma Sorunu & 10 \\
\hline & Dinleme Sorunu & 1 \\
\hline \multirow{2}{*}{ Çevresel Etkenler } & Teknolojinin Olumsuz Etkisi & 15 \\
\hline & Aile Etkeni & 13 \\
\hline \multirow{3}{*}{ Gereklilikler } & Firsat Eşitliği & 13 \\
\hline & Etkinlik Tasarımı & 8 \\
\hline & Dijital Yetkinlik & 2 \\
\hline
\end{tabular}

Yapılan içerik analizi sonucunda 15 kod oluşturulmuştur. Frekanslar incelendiğinde "Kontrol Zorluğu" ve "Teknolojinin Olumsuz Etkisi” en çok tekrar edilen (N=15), "Dinleme Sorunu" ise en az tekrar edilen ( $\mathrm{N}=1)$ kod olmuştur. Kodlara bağlı olarak ise "Ders Süreci”, "Beceri Alanları”, "Çevresel Etkenler” ve "Gereklilikler” şeklinde dört tema belirlenmiştir. Kodlar 
açıklanırken katılımcıların kişisel bilgilerinden ve yanıtlarından yola çıkılarak doğrudan alıntılara yer verilmiştir.

\section{Bulgular ve Yorumlar}

$\mathrm{Bu}$ bölümde araştırma kapsamında oluşturulan alt problemler yanıtlanmıştır. $\mathrm{Bu}$ çerçevede oluşturulan kod ve temalara ilişkin açıklamalara yer verilmiştir.

\section{Birinci alt probleme ilişkin bulgular ve yorum}

Çalışma kapsamında sınıf öğretmenlerine COVID-19 salgını sürecindeki uzaktan eğitimde Türkçe dersinde yaşadıkları sorunların neler olduğu sorulmuştur. Öğretmenlerin yanıtlarından yola çıkılarak "kontrol zorluğu, hareketsizlik, düşük motivasyon, dikkat eksikliği, verimliliğin azalması ve eksik katılım” kodları oluşturulmuştur. Kodlardan yola çıkılarak ise "ders süreci” temasına ulaşılmıştır. Oluşturulan tema ve kodlar Tablo 2'de verilmiştir.

\section{Tablo 2}

“Ders Süreci” Temasına İlişkin Frekanslar.

\begin{tabular}{|l|l|c|}
\hline Tema & Kod & Kod tekrar \\
\hline \multirow{5}{*}{ Ders Süreci } & Kontrol Zorluğu & 15 \\
\cline { 2 - 3 } & Hareketsizlik & 10 \\
\cline { 2 - 3 } & Düşük Motivasyon & 9 \\
\cline { 2 - 3 } & Dikkat Eksikliği & 9 \\
\cline { 2 - 3 } & Verimliliğin Azalması & 5 \\
\cline { 2 - 3 } & Eksik Katılım & 2 \\
\hline
\end{tabular}

Tablo 2'de de görüldüğü gibi “kontrol zorluğu” kodu katılımcılar tarafından 15 kez tekrar edilmiştir. Katılımcıların verdiği yanıtlardan bazıları aşağıda sunulmuştur.

"Gerekli hazırlık, ilgi çekici materyaller hazırlandıktan sonra dersler işlenebilir. Fakat kontrol etme, birebir yanlışlarını düzeltebilme, anında dönüt verebilme mümkün olmuyor." (6, K, 4. Sinıf, Şm.)

“Takibim ve kontrolüm daha zorlaştı. Takip edemediğimden haliyle yol da gösteremiyorum.” (8, K, 2. Sinıf, Şm.)

"Doğru okuma sorunu olanları düzeltemiyoruz çünkü araya girdiğin anda ses kesiliyor gelmiyor vb. vakit geçiyor.” (15, E, 4. Sınıf, Köy)

Alıntılarda da görüldüğü gibi 15 sınıf öğretmeni çevrim içi derslerde öğrencilerini ve öğrencilerinin çalışmalarını kontrol edemediklerini dile getirmiştir. Derslerde yaşanan bağlantı sorunları, aynı anda konuşmadan kaynaklanan ses problemleri kontrol etme sürecini 
zorlaştırmaktadır. Ayrıca öğrenci ürünlerinin ekranda net olarak görülmemesi de zorlaştırıcı bir etken olarak belirtilmektedir.

Tablo 2 incelendiğinde "hareketsizlik" koduna ilişsin olarak 10 sınıf öğretmeninin görüş bildirdiği görülmektedir. Bu koda yönelik olarak elde edilen yanıtlardan yapılan alıntılar aşağıda sunulmuştur.

“Özellikle drama gibi öğrencinin fiziki performansını sergilemesi gerektiği durumlarda uzaktan eğitim yetersiz kalmıştır.” (2, E, 3. Sınıf, Şm.)

“Öğrenciler beden dili hiç kullanamıyor.” (7, E, 4. Sınıf, Köy)

"Ders kitabında yer alan canlandırma etkinliklerini sınıf ortamındaki kadar başarılı bir şekilde ilerletemedik” (3, K, 3. Sınıf, Köy)

Alıntılar incelendiğinde de COVID-19 salgını sürecinde gerçekleştirilen çevrim içi Türkçe öğretimi derslerinde genel olarak eylemde bulunamama sorunu yaşanmıştır. Bu durum öğrencilerin beden dilini kullanamama sorununu da beraberinde getirmiştir. Ayrıca ders sürecinde hareketsiz olarak kalmaları öğrencilerin dikkatinin dağılmasına da yol açmıştır.

Tablo 2'de “düşük motivasyon” kodunun öğretmenler tarafindan dokuz kez belirtildiği görülmektedir. Öğretmenlerin ifadelerinden bazıları aşağıda sunulmuştur.

“Derse olan motivasyonlarının yüz yüze eğitime göre düşük olduğunu düşünüyorum” (2, E, 3. Sinıf, Şm.)

“Bu dönemde belki de en çok yaptıklarl şey dinlemek. Ama dinleme sırasında zihinlerinin aktif olduğunu düşünmüyorum. Çünkü sorduğum soruları en az iki kez tekrarlıyorum hatta bazı ögrencilerin mikrofonu açılınca aynı anda TV izledikleri için arkadan TV sesi geldiğine şahit oluyorum.” (14,E, 4. Sinıf, Köy)

"Uzaktan ĕgitim sürecinde öğrenci ve ögrretmenlerin çoğu zaman birbirlerini takip edememeleri ögrencilerin süreçte moralini bozmakta ve konuşma isteğini kırmaktadır.” (11,E, 4. Sinif, Ks.)

Uzaktan eğitim sürecinde öğrencilerin sınıf ortamının dışına çıkmış olması derse karşı ilgilerinin azalmasına neden olmuştur. Alıntılar incelendiğinde de öğrencilerin motivasyonlarının düşük olduğu ifade edilmektedir. Uzaktan eğitim sürecinde özellikle rekabet, sosyal kabul, öğretmenin takdirini kazanma gibi dişsal motivasyon bileşenleri etkisini yitirmektedir. Öğrenciler derse katılım konusunda isteksizlik göstermektedir.

Tablo 2 incelendiğinde "dikkat eksikliği”" kodunun katılımcılar tarafından dokuz kez tekrar edildiği görülmektedir. Katılımcıların verdiği yanıtlardan bazıları aşağıda sunulmaktadir. 
"Metin okuma ve anlama çalışmaları sırasında öğrencinin kontrol edilememesinden dolayı dikkatlerini yoğunlaştıramamalarına bă̆gl olarak istenilen zaman ve sürede ders bitirilememektedir.” (11,E, 4. Sinıf, Ks.)

“Öğrenciler odaklanma problemi yaşıyor.” (5,K, 1. Sınıf, Köy)

"Uzaktan ĕ̆itimden dolayı öğrencilerin dikkatinin sürekli dă̆ıldiğg bir ortam mevcuttur. Bu da dikkatli dinlemeyi azaltıyor" (7, E, 4. Sinıf, Köy)

Alıntılarda da görüldüğü gibi kullanılan aracın sahip olduğu uyarıcılar ve ders sürecinde yaşanan aksamalar nedeniyle öğrencilerin dikkatleri azalmaktadır. Ders sürecinde yaşanan ses iletim sorunu, görüntü donması, sistemden çıkma, internet açık olduğu için gelen medya dosyaları gibi nedenlerle öğrencinin dikkati çalışmaların üzerinde olsa bile dersten farklı unsurlara kayabilmektedir. Öğrencilerin ders içeriği yerine ders dışı unsurlara odaklanması öğrenme öğretme sürecini olumsuz etkilemektedir.

Tablo 2'ye bakıldığında “verimliliğin azalması” kodunun öğretmenler tarafından beş kez tekrar edildiği görülmektedir. Öğretmenlerin ifadelerinden bazıları aşağıda sunulmuştur.

"Birinci sınıf olduğum için. Ses verme, yazdırma ve uygulama kısımlarında büyük sorunlar yaşıyoruz. İstenilen hızda ve verimlilikte ilerlemek pek mümkün değil.” (5, K, 1. Sınıf, Köy)

“Bu aşamada hemen hemen tüm yazma çalışmaları dikteye döndü. Öğrencilerin kendilerinin oluşturacă̆ bir yazma çalışması yapılmadı. Bu durum özellikle bağımsız yazabilecek 4. sinıfları olumsuz etkiledi.” (14, E, 4. Sinıf, Köy)

"Teknolojiyi fazla kullandıkları için yazı çalışmalarına önem vermedikleri, yazı güzelliklerinin bozulduğu ve düşünerek yazıyla anlatım yapmak yerine kısa yoldan sonucu görmeye çalıştıklarını düşünüyorum.” (1, K, 3. Sınıf, Ks)

Alıntılar incelendiğinde uzaktan eğitimin sahip olduğu dezavantajlar nedeniyle yüz yüze eğitime göre verimliliğin azaldığı ifade edilmektedir. Etkinliklerin kontrolünün azalması, süre ve katılım eksikliği çalışmaların özensizce yapılmasına yol açmaktadır.

Tablo 2'de “eksik katılım” kodunun iki kez tekrar edildiği görülmektedir. Bu koda ilişkin olarak öğretmenlerin belirttiği ifadeler aşağıda sunulmuştur.

“Aynı öğrenciler devam etmediği için süreklilik olmadı her gün başka öğrenciyle ders işledim.” (15, E, 4. Sınıf, Köy)

“Öğrenciler derse eksik katıldılar.” (14, E, 4. Sınıf, Köy)

Katılımcıların ifadelerinde de görüldüğü gibi öğrencilerin bazılarının derse katılmadığı bazılarının ise katılımda süreklilik sağlamadığı belirlenmiştir. Bu durum öğrencilerin bir 
kısmının derse katılımda sorun yaşadığının bir göstergesi olarak görülebilir. Ayrıca eksik katılım koduna yönelik olarak yanıt veren öğretmenlerin köyde çalışıyor olması da kırsal bölgelerde uzaktan eğitimde ciddi aksamalar yaşandığını göstermektedir.

\section{İkinci alt probleme ilişkin bulgular ve yorum}

Sınıf öğretmenlerinden elde edilen yanıtlar 1şığında COVID-19 salgını sürecinde uzaktan eğitimde, Türkçe dersinin beceri alanlarına yönelik olarak yaşanan sorunlar tespit edilmiştir. $\mathrm{Bu}$ çerçevede "dinleme sorunu, konuşma sorunu, okuma sorunu, yazma sorunu" kodları belirlenmiş ve bunlar bir araya getirilerek "beceri alanları" temasına ulaşılmıştır. Oluşturulan Tema ve Kodlar Tablo 3'te verilmiştir.

\begin{tabular}{|c|c|c|}
\hline \multicolumn{3}{|c|}{$\begin{array}{l}\text { Tablo } 3 \\
\text { “Beceri Alanları” Temasına İlişkin Bilgiler. }\end{array}$} \\
\hline Tema & Kod & Kod tekrar \\
\hline \multirow{4}{*}{ Beceri Alanları } & Konuşma Sorunu & 14 \\
\hline & Yazma Sorunu & 13 \\
\hline & Okuma Sorunu & 10 \\
\hline & Dinleme Sorunu & 1 \\
\hline
\end{tabular}

Tablo 3 'te sınıf öğretmenlerinin uzaktan eğitimle Türkçe dersinde beceri alanlarına ait yaşadıkları sorunlara ilişskin veriler bulunmaktadır. "Konuşma sorunu” kodu öğretmenler tarafından $14 \mathrm{kez}$ tekrar edilmiştir. Alınan yanıtlardan bazıları aşağıda sunulmuştur.

“Zamanın kısıtlı olması nedeniyle sözlü anlatımda sorunlar yaşadık. Öğrenciler kısa, mutsuz ve isteksiz konuşuyor.” (4, K, 4. Sınıf, Şm.)

"Uzun ve anlamll cümleler kurmak yerine kendilerini ifade etmek için kısa cümleler kullanmaya başliyorlar.” (1, K, 3. Sinıf, Ks.)

"Uzaktan ĕgitimde sosyalleşme olmadı̆̆ için gelecekte kelime dă̆arcıkları kısıtlı olacak büyük ihtimalle." (5, K, 1. Sinıf, Köy)

Alıntılar incelendiğinde 14 sınıf öğretmeninin uzaktan eğitim sürecinde "konuşma sorunu" yaşadığını ifade ettiği görülmektedir. Öğrenciler sınıf ortamında bulunmadıkları için kendilerini ifade etmede güçlük yaşamaktadır. Derse sözlü olarak katılmak istememekte ve detaylı anlatım yapmamaktadır. İletişımde yaşanan aksaklıklar nedeniyle öğrencilerin konuşma isteğini kaybettikleri söylenebilir.

Tablo 3'te görüldüğü gibi “yazma sorunu” kodu katılımcılar tarafından 13 kez tekrar edilmiştir. Katılımcıların verdiği yanıtlardan bazıları aşağıda sunulmuştur. 
"Okuma yazma sürecinde yazma becerilerin geliştirilmesinde sorun yaşadım. Öğrencilerin yanlışlarına anında dönüt veremedim. Bu yüzden yazlları kötü. (13, E, 1. Sınıf, $\mathrm{Ks})$

"Yazma çalışmalarını uzaktan yapmak zor. Öğrenciler uzaktan metin oluşturmada sorunlar yaşadılar.” (14, E, 4. Sınıf, Köy)

“Öğrencinin kendini yazılı olarak ifade etmesi önceden de çok zordu. Şimdi de bu zorluk katlanarak devam etmektedir." (12, K, 4. Sinıf, Köy)

Alıntılarda da görüldüğü gibi öğretmenler öğrencilerin yazma becerisi ile ilgili çalışmalarda zorlandığını belirtmiştir. Oturum sürelerinin sınırlı ve yazmanın zaman alıcı bir çalışma olması, öğretmenlerin yazılı ürünleri kontrol edememesi nedeni ile uzaktan eğitim sürecinde özgün yazılı ürünler oluşturulamamıştır. Yazma çalışmalarına öğretmenler tarafından dönüt verilmesi konusunda zorluklar yaşanmıştır. Ayrıca uzaktan eğitim çalışmalarında 1. sınıf öğrencilerine harflerin yazımının öğretilmesinde de zorluklar yaşanmıştır.

Tablo 3'e bakıldığında öğretmenler $10 \mathrm{kez}$ "okuma sorunu" koduna ilişkin görüş belirtmiştir. Görüşlerden bazıları aşağıda sunulmuştur.

“Teknolojik yetersizlik ile görsel ve işitsel araçların elverişsizliği yüzünden okunan metin anlaşılmamaktadır.” (11,E, 4. Sinıf, Ks.)

“Doğru okuma sorunu olanları düzeltemiyoruz çünkü araya girdiğin anda ses kesiliyor, gelmiyor vb. vakit geçiyor. Dolayısılla doğru okuyamayan doğru anlayamaz.” (15, E, 4. Sınıf, Köy)

"Serbest okumalar yaptırarak daha çok okuduğunu anlamalarına yardımcı oluyorduk önceden. Ama şimdi bu okumalara çok yer veremiyoruz.” (12, K, 4. Sınıf, Köy)

Öğretmenlere göre uzaktan eğitim çalışmalarında sürenin yetersiz oluşu, öğrenicinin ev ortamında oluşu gibi nedenlerden dolayı okuma becerisine ilişkin olarak etkinlikler daha az yapılmıştır. Ayrıca okuma çalışmalarına ilişkin olarak öğrencilere dönüt verilmesi konusunda da zorluklar yaşanmış ya da hiç dönüt verilmemiştir. Uzaktan eğitimde anında düzeltme yapma olanağının az olması, okuma sırasında seslerin farklı bir şekilde gitmesi gibi çeşitli sorunlardan dolayı yanlış okumaların tekrarlanması durumu ortaya çıkmıştır.

Tablo 3'e bakıldığında "dinleme sorunu" kodu katılımcılar tarafından bir kez ifade edilmiştir. Koda ilişskin katılımcının verdiği yanıt aşağıda sunulmuştur.

"Dinleme becerileri tabii ki sıkıntılı. Internet ortamında bir sürü gürültü, evin içinde de öyle. Etkin dinleyemiyorlar.” (5, K, 1. Sinıf, Köy). 
Yanıtlar içerisinde dinleme becerisine ilişkin sadece bir öğretmenin sorun yaşadığını belirtmiş olması dinlemenin genel olarak uzaktan eğitimden etkilenmediğini göstermektedir. Uzaktan eğitimde dersler çoğu kez düz anlatımla işlenmiştir. Öğrenciler, derslerin önemli bölümünde dinlemeye yer vermiştir. Bu konuda bir öğretmen "anlamak için öğrencinin iyi dinlemekten başka seçeneği yok" ifadesine yer vermiştir. Yanıttan yola çıkılarak uzaktan eğitim çalışmalarında derslerin dinleme ağırlıklı olarak gerçekleştirildiği söylenebilir.

\section{Üçüncü Alt Probleme İlişkin Bulgular ve Yorum}

Öğretmenlere, COVID-19 salgını sürecindeki uzaktan eğitimde Türkçe dersi öğretimine etki eden çevresel etkenlerin neler olduğu sorulmuştur. Elde edilen verilerden "teknolojinin olumsuz etkisi, aile faktörü” kodları oluşturulmuş ve “çevresel etkenler” temasına ulaşılmıştır. Tema ve kodlara ilişkin bilgiler Tablo 4'te verilmiştir.

\begin{tabular}{|c|c|c|}
\hline $\begin{array}{l}\text { Tablo } 4 \\
\text { “Çevresel Etkenler }\end{array}$ & nasına İlişkin Bilgiler. & \\
\hline Tema & Kod & Kod tekrar \\
\hline \multirow{2}{*}{ Çevresel Etkenler } & Teknolojinin Olumsuz Etkisi & 15 \\
\hline & Aile Etkeni & 13 \\
\hline
\end{tabular}

Tablo 4'te görüldüğü gibi “teknolojinin olumsuz etkisi” kodu katılımcılar tarafindan 15 kez tekrar edilmiştir. Katılımcıların verdiği yanıtlardan bazıları aşağıda sunulmuştur.

“Öğretmenin konuşmasını anlayamadıkları için yazı çalışmalarında sorun yaşadık. Ekran paylaşımı yapıp yazarak onlara yazma çalışması yaptırabildim. Okuma yaparken sesler karıştı.” (1, K, 3. Sınıf, Ks.)

"Öğrenciler bir yandan kamera ve telefonla da ilgilendikleri için rahat konuşamıyorlar. Çoğu kez elleri telefona bağlı konuşuyorlar.” (14, E, 4. Sınıf, Köy).

“Öğrenciler ile iletişimde bazen kopukluklar yaşadım.” (2, E, 3. Sınıf, Şm.)

Alıntılarda da görüldüğü gibi öğretmenler, teknolojiden kaynaklı sorunların uzaktan eğitim sürecini aksattığını ifade etmektedir. Çevrimiçi programlarda aynı anda birden çok kişi konuşması ile ses karışıklıklarının yaşanması, dijital aygıttan ya da sistemden kaynaklanan nedenlerle seslerin doğru iletilmemesi gibi sorunlar yaşanmıştır. Bu durum öğretmen öğrenci, arasında ve öğrenciler arasında iletişim sorunları yaşanmasına neden olmuştur. Telefon ve tabletle bağlanan öğrenciler, araçları tutmak ve seslerinin daha iyi gitmesi konusunda çaba 
göstermek durumunda kaldığında da beden dilini kullanılamaması sorunu da ortaya çıkmıştır. Ayrıca alt yapı sorunlarından kaynaklı olarak istenmeyen zamanlarda/durumlarda dersten kendiliğinden ayrılma durumları da yaşanmıştır.

Tablo 4'e bakıldığında öğretmenlerin, “aile etkeni” kodunu 13 kez tekrar ettikleri görülmektedir. Öğretmenlerin verdiği yanıtlardan bazıları aşağıda sunulmuştur.

"Bazı ögrencilerim veli yanlarında olunca konuşmaktan çekiniyorlar ve kendilerini ifade edemiyorlar.” (8, K, 2. Sinıf, Şm.)

"Bulunduğu ortam ders için uygun hale getirilmiş ise bir problem olmuyor. Değil ise sağllklı bir şekilde ders dinlenmiyor.” (6, K, 2. Sınıf, Şm.)

"Çoğu öğrencinin kendisine ait odası ve çalışma masasının olmaması, evlerin klş mevsiminde soba ile ısınması ve buna bağgl olarak bütün aile aynı odada oturmaları ögrencilerin dikkatlerini dăğtmakta ve dersin akışını bozmaktadır.” (11,E, 4. Sınıf, Ks.)

Uzaktan eğitimle öğrenciler, öğretmenlerinin yanı sıra okulun sağladığı nitelikli öğrenme öğretme ortamından da yoksun kalmıştır. Sosyo-ekonomik düzeyi düşük ailelerde çocukların kendilerine ait bir masası ya da odası bulunmamaktadır. Çeşitli nedenlerden dolayı ev halkının aynı odayı kullanıyor olması öğrencinin öğrenme öğretme sürecine olumsuz etki yapmıştır. Ortaya çıkan bu durum öğrencinin akademik başarısını ortaya koymasında ve öğrenme etkinliklerini gerçekleştirmesinde sorunlara neden olmuştur.

\section{Dördüncü Alt Probleme İlişkin Bulgular ve Yorum}

Çalışma kapsamında uzaktan eğitimde karşılaşılan sorunları en aza indirmek ve süreci daha verimli yürütebilmek için yapılması gerekenler araştırılmıştır. Bu çerçevede "fırsat eşitliği”, “etkinlik tasarımı” ve dijital okuryazarlık” kodları oluşturulmuştur. Kodlar bir araya getirilerek "gereklilikler" teması oluşturulmuştur. Oluşturulan tema ve kodlar Tablo 5'te verilmiştir.

\begin{tabular}{|c|c|c|}
\hline \multicolumn{3}{|c|}{$\begin{array}{l}\text { Tablo } 5 \\
\text { “Gereklilikler” Temasına İlişkin Bilgiler. }\end{array}$} \\
\hline Tema & Kod & Kod tekrar \\
\hline \multirow{3}{*}{ Gereklilikler } & Firsat Eşitliği & 13 \\
\hline & Etkinlik Tasarımı & 8 \\
\hline & Dijital Yetkinlik & 2 \\
\hline
\end{tabular}


Tablo 5'e bakıldığında “fırsat eşitliği”" kodu katılımcılar tarafından 13 kez tekrar edilmiştir. Katılımcıların yanıtlarından bazıları aşağıda sunulmuştur.

"Uzaktan eğitim için öğrencinin ev ortamının ve internet alt yapısının iyi olması lazım öncelikle. Bir de video ve fotoğraf gibi destekleyici ĕ̆itim materyallerinin zenginleştirilmesi." (5, K, 1. Sinıf, Köy)

"Kesinlikle 10 kişiyi geçmeyen küçük gruplarla devam etmeli. Kameralar her iki tarafinda açık olmall. Ayrıca internet ve bilgisayar alt yapısı gelişstirilmelidir.” (14, E, 4. Sınıf, Köy)

“Tüm ögrencilerimizin imkanlarının eşit olması gerekir.” (10, K, 4. Sınıf, Köy)

Alıntılarda, öğretmenlerin (13 katılımcı) başarılı bir uzaktan eğitim süreci için fırsat eşitliği sağlanması gerektiğini önerdiği görülmektedir. Çünkü uzaktan eğitim süreci teknoloji temelli olarak yürütülmektedir. Teknolojik araç ve altyapı yetersizlikleri öğrencilerin katılımını azaltmaktadır. Katılımcılara göre COVID-19 salgını sürecindeki uzaktan eğitimde firsat eşitliğine uymayan durumlar fazlasıyla yaşanmıştır. İnterneti, bilgisayarı ya da hem interneti hem de bilgisayarı olmayan öğrencilerin uzaktan eğitim sürecinde yer alması pek mümkün olmamıştır. Bu durumun öğrencilerde öğrenme kayıplarına neden olabileceği öngörülebilir. Ayrıca öğrencilerin uzaktan eğitim şartlarının iyileştirilmesi derse katılım sorununu da belli boyutlarda çözebilecektir.

Tablo 5'te görüldüğü gibi “etkinlik tasarımı” kodu katılımcılar tarafından sekiz kez tekrar edilmiştir. Katılımcıların verdiği yanıtlardan bazıları aşağıda sunulmuştur.

“Özellikle ögrencilerin dikkatini çekecek etkinlikler tasarlanmalıdır. Örneğin; kusa videolar, animasyonlar ve ilgi çekici slaytlar ders bazlı hazırlanıp tema tema ögretmenlerin kullanımına sunulmalıdır.” (2, E, 3. Sinıf, Şm.)

"Daha çok etkileşimli ve ona göre hazırlanmış materyaller olmalıdır. Bazı konuşma veya yazma bölümleri yüz yüze eğitime göre tasarlanmış ama uzaktan olarak uygulanıyor.” (15, E, 4. Sinıf, Köy)

“Önceden hazırlanmış sunular olmalı. Hayal dünyalarını ve enerjilerini kullanabilecek etkinliklere yer verilmeli. Oyunlaştırarak, keş̧fettirerek öğretmeye çalışılmalıdır.” (6, K, 2. Sinıf, Şm.)

Araştırmaya katılan sekiz öğretmen bazı etkinliklerin uzaktan eğitim sürecinde kullanılmaya uygun olmadığını çünkü bunların yüz yüze dersler için geliştirilmiş olduğunu belirtmiştir. $\mathrm{Bu}$ nedenle öğretmenler bu etkinliklerin uygulanmasında sorun yaşamaktadır. Uzaktan ve yüz yüze eğitim kendi içinde farklılıklar taşımaktadır. Bu nedenle uzaktan eğitimde 
kullanılabilecek oyunlaştırılmış, etkileşimli ve teknoloji destekli etkinlikler verimliliğin artmasına katkı sağlayabilir.

Tablo 5'e bakıldığında “dijital yetkinlik” kodunun iki kez tekrar edildiği görülmektedir. Katılımcıların koda ilişkin yanıtları aşağıda sunulmuştur.

"Öğrencilerin ve velilerin uzaktan eğitimde teknoloji bilgilerinin daha fazla olması gerekiyor.” (1, K, 3. Sinıf, Ks.)

"En başta uzaktan ĕgitim konusunda ögretmenlerin uzman olmalarl; nerede, ne zaman, neyi nasıl yapacaklarını çok iyi biliyor olmaları gereklidir. Öğretmenin, öğrencinin dikkatini toplayacak, onun merakını uyandıracak her türlü tedbiri dijital ortamda önceden alması ve olası bir sorunda ne yapabileceğini bilmesi gereklidir.” (11, E, 4. Sınıf, Ks.)

Alıntılarda da görüldüğü gibi öğretmenlerden ikisi dijital yetkinlik kavramını ifade etmektedir. Katılımcılara göre öğretmen, öğrenci ve veliler dijital yetkinlik konusunda sorun yaşamaktadır. Dijital araçların öğrenme ortamında sunduğu olanaklardan yararlanma ve olası sorunlara çözüm üretebilmenin ders sürecini etkilediği vurgulanmaktadır. Etkili bir uzaktan eğitim süreci için öğretmen ve öğrencilerin dijital araçları kullanabilmeleri gerekmektedir. 


\section{Sonuç, Tartışma ve Öneriler}

Araştırma sonucunda elde edilen bulgular incelendiğinde salgın sürecinde yaşanan uzaktan eğitimle Türkçe dersinde, öğretmenlerin ders süreci içerisinde yaşadıkları sorunlar belirtilmiştir. Uzaktan eğitim sürecinde öğretmenler $(n=15)$ kontrol zorluğu, hareketsizlik $(n=10)$ ve düşük motivasyon $(n=9)$ sorunları yaşadıklarını ifade etmişlerdir. Öğrenciler tarafından yapılan etkinlikleri kontrol etmek ve dönüt vermek kısıtlı düzeyde mümkün olmaktadır. Öğrenciler, elleri dijital araçlara bağlı olarak derse katılmaktadır. Ders boyunca hareket edememekte, konuşma sırasında beden dilini kullanamamaktadır. İlkokul öğrencilerinin ders boyunca hareketsiz kalmaları gelişsim özelliklerine aykırıdır. Bütün bunlar öğrencilerin dikkatinin dağılmasına neden olmaktadır. $\mathrm{Bu}$ durum onların öğrenme motivasyonlarının düşmesine neden olabilmektedir. Elde edilen bu sonuçlar daha önce yapılan çalışmaları destekler niteliktedir. Daha önce yapılan çalışmalara göre arkadaşlarından ayrı ortamlarda ders işleyen öğrencilerin rekabet, taktir edilme, çalışkan olma gibi dışsal motivasyon duyguları ortadan kalktığı için derse yönelik ilgilerinde azalma olmaktadır. Çoğu kez ders dinlemenin yanında başka şeylerle de uğraştıkları öğretmenlerce fark edilmekte ve yöneltilen sorular tekrar edilmektedir. $\mathrm{Bu}$ süreçte benzer olarak öğrencilerin derse katılımlarının az ve motivasyonlarının düşük olduğunu ve bunların yükseltilmesi gerektiğini vurgulayan çalışmalar bulunmaktadır (Bakioğlu ve Çevik, 2020; Balaman ve Hanbay-Tiryaki, 2021; Bozkurt, 2020; Canpolat ve Yıldırım, 2021; Karaca, Karaca, Karamustafaoğlu ve Özcan 2021). Putri ve diğerleri (2020) yaptıkları çalışmayla Endonezya'da, ilkokullarda, COVID-19 salgını sürecinde çevrim içi derslerde yaşanan sorunları tespit etmeyi amaçlamıştır. Araştırmada 15 öğretmen, 2 veli ile görüşmeler yapılmıştır. Çalışmanın sonuçlarına göre öğrenciler çevrim içi derslerde uzun süre hareketsiz kaldıkları için bedenlerini kullanamama sorunu yaşamışlardır.

Atmojo ve Arif Nugroho (2020) Endonezya'da ortaokullarda görev yapan 16 İngilizce öğretmeni ile bir araştırma yapmıştır. Bu çalışma ile ortaokullarda görev yapan İngilizce öğretmenlerinin COVID-19 salgınındaki uzaktan eğitimde İngilizce öğretiminde karşılaştıkları sorunlar tespit edilmeye çalışılmıştır. Öğretmenler eş zamanlı yaptıkları derslerde öğrencileri kontrol etmenin zorluğunu dile getirmiştir. Kurnaz ve Serçemeli (2020) de çevrimiçi derslerde üniversite öğrencileriyle etkileşimin az olduğunu bundan dolayı öğrencileri ve ders sürecini kontrol etmekte zorlandıklarını dile getirmiştir. Kontrolün zor olması da öğrencilerin ilgisini azaltmaktadır. 
Öğretmenler, uzaktan eğitimde dikkat eksikliği $(n=9)$, verimliliğin azalması $(n=5)$ ve eksik katılım $(n=2)$ sorunları yaşadığını belirtmiştir. Öğretmenlerin görüşlerine göre ders sürecinde öğrenciler televizyon izlemekte, soruları yanıtsız birakmakta ve derse odaklanmamaktadır. Benzer şekilde Avcı ve Akdeniz (2021), öğrencilerin uzaktan eğitimde dikkat sorunu yaşadığını ifade etmiştir. Yurtbakan ve Akyıldız (2020) ise uzaktan derslerde verimliliğin azaldığını ortaya koymaktadır. Verimliliği azaltan nedenlerden birisi de öğrencilerin birbiriyle iletişim kurmadan ders işlemeleridir. Kamera ve sesin kapatıldığ1 durumlarda öğrenciler ders dışı etkinliklerle ilgilenebilmektedir. Öğrenciler, arkadaşlarıyla iletişim kuramadığı için yalnızlık hissine kapılıp depresyona girmektedir (Balaman ve HanbayTiryaki, 2021; Baloran, 2020). Etkileşim miktarını arttırmak, bireylerdeki izolasyon duygusunu en aza indirmekte ve etkin katılımı arttırmaktadır (Yıldız, 2020). Uzaktan eğitim sürecinde öğrenciler; bağımsız çalışma yapamamakta, öğretmen kontrolü olmadığı ve aileler denetim mekanizmalarını etkin kullanamadığı için özenli çalışmamaktadır. Ayrıca çevrimiçi derslerde, her oturumda farklı katılımcılar yer alabilmektedir. Bu da derslerin öğrenilmesinde süreklilik sağlanamaması ve verimliliğin azalması sorununu ortaya çıkarmaktadır. Bu sonuçlar Karaca ve diğerlerinin (2021) çalışmasını desteklemektedir. Türkçe öğretmenleri çevrimiçi derslerin karne notuna katkısı ve devam zorunluluğu olmaması nedeniyle katılımın zamanla azaldığını belirtmektedir (Bayburtlu, 2020). Erkoca (2021), üniversite öğrencilerinin ilk iki hafta çevrimiçi derslere katıldığını daha sonra derse katılım ve ilginin giderek azaldığını dile getirmiştir. Final sınavları öncesinde öğrencilerin \%25'i derslere katılmaya devam etmektedir. Sonuçlar uzaktan eğitimde sürekli katılım sorununun eğitimin her aşamasında olduğunu göstermektedir.

Araştırma, uzaktan eğitimde Türkçe dersi kapsamındaki beceri alanlarında çeşitli sorunlar yaşandığını ortaya koymuştur. Öğretmenler, dört temel dil becerisi içerisinde sırasıyla konuşma $(n=14)$, yazma $(n=13)$, okuma $(n=10)$ ve dinleme $(n=1)$ becerilerinde sorun yaşadıklarını ifade etmiş̧tir. Sirem ve Baş (2020) ise uzaktan eğitimde okuma güçlüğü yaşayan öğrencilerin yazma ürünleri oluştururken zorlandıklarını ancak okuma becerilerinin geliştiğini belirtmiştir. Yine okuma yanlışlarının anında düzeltilememesi ve yazma çalışmalarına dönüt verilememesi uzaktan eğitimin sorunları olarak vurgulanmıştır. Ayrıca bu nedenlere bağlı olarak 1. sınıf öğretmenleri ilk okuma-yazma öğretimi sürecinde daha çok zorlanmıştır. Kamal, Zubanova, Isaeva ve Movchun (2021) Birleşik Arap Emirlikleri ve Rusya'da iki ayrı üniversitede 103 öğrenci ile İngilizce öğrenimine yönelik olarak survey çalışması yapmıştır. $\mathrm{Bu}$ çalışma ile COVID-19 salgınında eğitim sürecindeki bilişsel yeteneklerdeki ve akademik 
performanstaki değişikliklerin belirlenmesi amaçlanmıştır. Yapılan çalışmaya göre öğrencilerin konuşma, yazma ve okuma ile ilgili görevleri yerine getirmede salgın sürecinden öncesine göre düşüşler olduğu belirlenmiştir. Kavuk ve Demirtaş (2021), araştırmalarında birinci sınıf öğretmenleriyle ilgili benzer sonuçlara ulaşmıştır. İletişim kopuklukları, zamanın kısıtlı olması öğrencileri kısa ve isteksiz konuşmaya itmiştir. Canpolat ve Yıldırım'ın (2021) araştırmasında da öğretmenler, 1. sınıflarla yapılan uzaktan eğitimde sorunlar yaşadıklarını dile getirmiştir. Katılımcılar, çözüm olarak çevrimiçi derslerde tartışma ortamı oluşturarak öğrencilerin yorumlarını dinlemeyi seçmiştir. Çalışma kapsamında beceri alanlarına ilişkin belirlenen sorunlar önceki araştırmalarla örtüşmektedir. Aydın ve Erol (2021) da yaptıkları çalışma ile birinci sınıf öğretmenlerinin COVID-19 sürecindeki uzaktan eğitimde alt yapı yetersizliğinden dolayı teknolojik sorunlar yaşadığını belirtmiştir.

Uzaktan eğitimde teknolojinin olumsuz etkisi $(n=15)$ kodu kapsamında gerek sistem gerekse dijital aygıtlardan kaynaklanan sorunlar yaşandığ 1 tespit edilmiştir. Uzaktan eğitim, teknoloji temelli yürütülmektedir. Ders içerisinde sayfaların geç yüklenmesi, bağlantı kopması, kullanılan uygulamaların yetersizliği gibi sorunlar yaşanmıştır. Keskin ve Özer-Kaya (2020), öğrencilerin yarıdan fazlasının çevrimiçi derslerde sorun yaşadığını ifade etmektedir. Aynı şekilde Gökbulut (2021), internet tabanlı uzaktan eğitimde birtakım derse katılım sorunları yaşandığını doğrulamaktadır. Öğrenciler, ders içerisinde dijital araçlara gelen bildirimlerle ilgilenmiştir. Atay ve Mahmoudi (2021) yaptıkları nitel çalışmada 177 hukuk fakültesi öğrencisine ulaşmış ve öğrencilerin COVID-19 salgınındaki uzaktan eğitimde yaşadıkları sorunları tespit etmeye çalışmıştır. Öğrencilerin görüşlerine göre derslerde telefon ve diğer çevrimiçi uygulamalar nedeniyle teknik sorunlar yaşanmıştır. Fauzi ve Khusuma (2021) 45 ortaokul öğretmeni ile yaptıkları araştırmada öğretmenlerin COVID-19 sürecindeki çevrim içi derslere ilişkin değerlendirmelerini belirlemeyi amaçlamıştır. Araştırmanın sonuçlarına göre öğretmenler teknolojik engellerden (internet bağlantısı, internet kotası, alt yap1 yetersizliği vb.) dolayı derslerde sorun yaşamıştır. Ariyanti (2020) sekiz üniversite öğrencisi ile yaptığı görüşmelerde COVID-19 salgını sürecinde yaşadıkları sorunları tespit etmeye çalışmıştır. Araştırmanın sonucuna göre öğrenciler çevrim içi derslerde internet bağlantısı konusunda sorun yaşamışlardır.

Araştırmadan elde edilen başka bir sonuca göre aile etkeni $(n=13)$ kodu kapsamında ev ortamından kaynaklanan sorunlar yaşandığı belirlenmiştir. COVID-19 salgındaki uzaktan eğitimde ev ortamında ders görme ve ailenin sahip olduğu olanaklar süreci etkilemiştir. Mevsim şartları nedeniyle aynı odada birden çok kişinin bulunması, velilerin yargılayıcı 
tutumları öğrencilerin konu dışındaki etkenlerle ilgilenmesine ve iletişim kuramamasına neden olmuştur. Bu sonuçlara benzer olarak öğrencilerin, aile bireyleriyle aynı odada bulunduğu için dikkatlerinin dağıldığı, kardeş, vb. yakınlarınca rahatsız edildiği ve ailelerin uzaktan eğitime uygun ortam hazırlayamadığı ortaya çıkmıştır (Avcı ve Akdeniz, 2021; Kavuk ve Demirtaş, 2021). Bayburtlu (2020), velilerin bilgilendirilmesinin uzaktan eğitim sürecini daha etkili hale getireceği sonucuna ulaşmıştır. Atay ve Mahmoudi (2021) de COVID-19 salgınındaki çevrimiçi derslerin zaman zaman aile üyeleri tarafından kesintiye uğratıldığı belirlenmiştir. Bu durum öğrencilerin derslerine odaklanmalarına engel teşkil etmiştir. Öğrencinin bulunduğu çevrenin ve ailenin sosyo-ekonomik durumunun uzaktan eğitim sürecinde çok etkili olduğu sonucu önceden yapılan çalışmaları destekler niteliktedir. Efriana (2021) yaptığı çalışma ile COVID-19 salgını sürecinde İngilizce öğretmenlerinin öğrenci ve velilerle çevrim içi öğrenmede çeşitli zorluklar yaşadığını belirlemiştir. Putri ve diğerleri (2020) yaptıkları araştırmada veliler COVID-19 sürecindeki çevrim içi derslerde öğrenme disiplinini sağlayamadıklarını belirtmiştir.

Araştırmanın sonuçlarına göre uzaktan eğitim sürecinde firsat eşitliğinin sosyoekonomik düzeyi düşük ailelerin çocuklarında bozulduğu $(n=13)$; sürecin yapısına uygun etkinlik tasarımının yeterli sayıda olmadığı $(n=8)$; dijital yetkinlik konusunda öğretmen, öğrenci ve velilerin sorun yaşadığı $(n=2)$ ortaya çıkarılmıştır. Öğretmenlere göre sosyoekonomik düzeyi düşük ailelerin çocukları uzaktan eğitim sürecinden yeterince yararlanamamıştır. Çünkü bu aileler gerekli dijital aygıtlara ya da internete sahip değildir. Fırsat eşitliğine uymayan koşullarda uzaktan eğitime katılamayan ya da az katılan öğrencilerin çok büyük ölçüde öğrenme kaybı yaşadığı öngörülebilir bir durumdur. Bu konuda elde edilen sonuçlar yapılan diğer çalışmaları da destekler niteliktedir. Bu araştırmalar da öğrencilerin bilgisayar ve internete ya da ikisinden birine erişemedikleri için derslere katılamadıklarını göstermektedir (Bakioğlu ve Çevik, 2020; Balaman ve Hanbay-Tiryaki, 2021; Bayburtlu, 2020; Bozkurt, 2020). Başka bir araştırmada üniversite öğrencilerinin \%37'sinin evinde internet olmadığ 1 ve çevrim içi derse girmeyenlerin \%75'inin internet yetersizliği nedeniyle derslere katılamadığı belirlenmiştir (Karadağ ve Yücel, 2020). Sezgin ve Firat (2020) tarafından dijital uçurum olarak belirtilen bu durum, öğrencilerin yaşadığ 1 firsat eşitsizliğinin gerekçelerini arttırmıştır. Sosyo-ekonomik nedenler, coğrafi nedenler gibi gerekçelerin yanına teknolojik nedenler boyutunun da eklendiği belirtilmiştir. Araştırma verileri birbirini destekler niteliktedir. Ancak üniversite öğrencileri ile yapılan başka bir araştırmada, öğrencilerin neredeyse tamamının uzaktan eğitime bağlanabilecek bir dijital araca (telefon, tablet, bilgisayar 
vb.) ve internet hattına sahip olduğu ortaya konulmuştur. $\mathrm{Bu}$ durumun nedeni olarak da öğrencilerin yaş düzeyinden dolayı telefon sahibi olmasının etkili olduğu belirtilmiştir (Karatepe, Küçükgençay ve Peker, 2020). Uzaktan eğitimde kullanılan ders materyalleri yüz yüze eğitime yönelik tasarlandığı için uyum sorunları yaşanmaktadır. Bu nedenle sürece uygun etkinlik tasarlanmasının gerekliliği ortaya çıkmıştır. Yıldız (2020), çevrim içi ortamlarda topluluk hissi sağlanması ve öğretimin gerçekleşmesi için materyal tasarımının etkili olduğunu ifade etmektedir. İşbirliği, etkileşim ve güven ortamının sağlanmasında öğrencilerin ilgisine göre yapılan tasarımların etkili olacağı belirtilmiştir. Atmojo ve Arif Nugroho (2020) da yaptıkları çalışmada öğretmen görüşlerine göre COVID-19 sürecinde çevrim içi derslere velilerin ilgisiz kaldığını belirlemiştir. Veliler özellikle çocuklarının çevrim içi derslere katılmasını ve bunu sürdürmesini yeterince takip etmemiştir.

Katılımcılara göre öğretmen, öğrenci ve ailelerin dijital yetkinliğe sahip olması, kullanılan araçların eğitim-öğretim ortamlarında sunduğu olanaklardan yararlanma açısından önemlidir. $\mathrm{Bu}$ araştırmadan elde edilen bulgular daha önce yapılan çalışmaları destekler niteliktedir. Arslan, Görgülü-Arı ve Hayır-Kanat'ın (2021) araştırmasında veliler, teknoloji kullanımı konusundaki eksikliklerinin uzaktan eğitim sürecini aksattığını belirtmektedir. $\mathrm{Bu}$ konuda yapılan diğer çalışmalar da teknoloji kullanımını belirli bir düzeyde bilmenin uzaktan eğitimdeki önemine vurgu yapmaktadır. Bu çalışmalarda öğretmen, öğrenci, velilerin uzaktan öğrenme ve bilişim teknolojileri konusunda eğitilmesinin sürecin daha sağlıklı yürütülmesine katk1 sağlayacağı ifade edilmektedir (Can, 2020; Canpolat ve Yıldırım 2021). Uzaktan eğitimde dijital araçların kullanımıyla ilgili öğretim elemanlarına eğitim verilmişstir. Deneysel çalışma sonucunda öğretim elemanlarının öz yeterliliklerinin yükseldiği görülmüştür (Ak, Gökdaş, Öksüz ve Torun, 2021). Öğretmen, öğrenci ve velilerin teknoloji kullanımı konusundaki yetkinlikleri gerek salgın sürecinde gerekse salgın sonrasında onlara büyük kolaylıklar sağlayabilir. Ariyanti (2020) üniversite öğrencileri ile yaptığı araştırmada COVID19 salgını sürecindeki çevrim içi derslerde dijital uygulamalarda sorun yaşandığını belirlemiştir. Putri ve diğerleri (2020) ilkokul öğrencileri ile yaptığı çalışmada özellikle 4. Sınıf öğrencilerinin teknoloji becerileri eksikliğinden dolayı çevrimiçi derslerde sorun yaşadıklarını belirlemiştir. 
Araştırma sonuçlarına göre aşağıdaki öneriler sunulmuştur.

- COVID-19 sürecinde ve sonrasında dijital yetkinliğin önemi göz önüne alınarak öğretmen, veli ve öğrencilere eğitimler verilmelidir.

- Uzaktan eğitim ile ilk okuma yazma öğrenen öğrencilerin harflerin yazım yönlerini ne kadar iyi bildiğine ilişkin araştırmalar yapılmalı ve gerekirse bu konuda telafi eğitimleri verilmelidir.

- Fırsat eşitliğinin sağlanması adına uzaktan eğitim sürecinde devam sorunu yaşayan öğrenciler için özel bir telafi programı hazırlanmalı ve ilerleyen eğitim kademelerinde eksiklerini tamamlayamayanlar için gerekli çalışmalar yapılmalıdır.

- Uzaktan eğitimi daha etkili bir hale getirmek için öğrenciler arasında etkileşimi arttıracak etkinlikler düzenlenmelidir. Süreç içerisinde öğrenmelerin daha etkili gerçekleşmesi için MEB desteği ile eğitim materyalleri hazırlanmalıdır.

- Araştırmacılar, faklı öğretim kademelerine göre uzaktan eğitimde yaşanan sorunları ve tespit etmek için yeni çalışmalar yapmalıdır. 


\section{Kaynakça}

Akyürek, M. İ. (2020). Uzaktan eğitim: Bir alan yazın taraması. Medeniyet Ĕ̆gitim Araştırmaları Dergisi, 4 (1), 1-9.

Ak, Ş., Gökdaş, İ., Öksüz, C. ve Torun, F. (2021). Uzaktan eğitimde eğiticilerin eğitimi: Uzaktan eğitime yönelik öz yeterlik ve yarar algısına etkisi. Açıkögretim Uygulamaları ve Araştırmaları Dergisi(AUAd), 7 (1), 24-44.

Altunbay, M. ve Bıçak, N. (2018). Türkçe eğitimi derslerinde “Z kuşağı” bireylerine uygun teknoloji tabanlı uygulamaların kullanımı. Zeitschrift für die Welt der Türken Journal of World of Turks (ZfWT), 10 (1), 127-142.

Ariyanti, A. (2020). EFL Students' challenges towards home learning policy during Covid-19 outbreak. Indonesian Journal of English Language Teaching and Applied Linguistics, 5 (1), 167-175.

Arslan, K., Görgülü-Arı, A. ve Hayır-Kanat, M. (2021). Covid-19 pandemi sürecinde verilen uzaktan eğitim hakkında veli görüşleri. Ulakbilge Sosyal Bilimler Dergisi, 57, 192-206.

Atay, F. ve Mahmoudi, A. (2021) Hukuk öğrencilerinin Covid-19 pandemisi sırasında çevrimiçi mesleki yabancı dil kursu öğretimine ilişkin görüşleri. Uluslararası Eğitim Spektrumu Dergisi, 3 (1), 92-104.

Atmojo, A. E. P., \& Nugroho, A. (2020). EFL classes must go online! Teaching activities and challenges during COVID-19 pandemic in Indonesia. Register Journal, 13 (1), 49-76.

Avcı, F. ve Akdeniz, E. C. (2021). Koronavirüs (Covid-19) salgını ve uzaktan eğitim sürecinde karşılaşılan sorunlar konusunda öğretmenlerin değerlendirmeleri. Uluslararası Sosyal Bilimler ve Ĕgitim Dergisi, 3 (4), 117-154.

Ayda, N. K., Baştaş, M., Altınay, F., Altınay, Z. ve Dağlı, G. (2020). Distance education for students with special needs in primary schools in the period of Covid-19 epidemic. Propositos y Representaciones, 8 (3), 1-8.

Aydın, E. ve Erol, S. (2021). The views of Turkish language teachers on distance education and digital literacy during Covid-19 pandemic. International Journal of Education \& Literacy Studies. 9 (1), 60-71.

Bakioğlu, B. ve Çevik, M. (2020). COVID-19 pandemisi sürecinde fen bilimleri öğretmenlerinin uzaktan eğitime ilişkin görüşleri. Turkish Studies, 15 (4), 109-129.

Balaman, F. ve Hanbay Tiryaki, S. (2021). Corona virüs (Covid-19) nedeniyle mecburi yürütülen uzaktan eğitim hakkında öğretmen görüşleri. İnsan ve Toplum Bilimleri Araştırmaları Dergisi, 10 (1), 52-84. 
Baloran, E. T. (2020). Knowledge, attitudes, anxiety, and coping strategies of students during COVID-19 pandemic. Journal of Loss and Trauma, 25 (8), 635-642.

Barış, M. F. (2015). Üniversite öğrencilerinin uzaktan öğretime yönelik tutumlarının incelenmesi: Namık Kemal Üniversitesi örneği. Sakarya University Journal of Education, 5 (2), 36-46.

Başar, M., Arslan, S., Günsel, E. ve Akpınar, M. (2019). Öğretmen adaylarının uzaktan eğitim alg1s1. Journal of Multidisciplinary Studies in Education, 3 (2), 14-22.

Bayburtlu, Y.S. (2020). Covid-19 pandemi dönemi uzaktan eğitim sürecinde öğretmen görüşlerine göre Türkçe eğitimi. Turkish Studies, 15 (4), 131-151.

Bei, E., Mavroidis, I., \& Giosos, Y. (2019). Development of a scale for measuring the leraner autonomy of distance education students. European Journal of Open, Distance and eLearning, 22 (2), 133-144.

Bouznad, S., \& Ibourk, A. (2020). School closures, equality of opportunity: Some recommendations. Revista Romaneasca pentru Educatie Multidimensionala, 12 (1), 103110. https://doi.org/10.18662/rrem/12.2Sup1/295.

Bozkurt, A. (2020). Koronavirüs (COVID-19) pandemisi sırasında ilköğretim öğrencilerinin uzaktan eğitime yönelik imge ve algıları: Bir metafor analizi. Uşak Üniversitesi Ĕgitim Araştırmaları Dergisi, 6 (2), 1- 23.

Can, E. (2020). Coronavirüs (Covid 19) pandemisi ve pedagojik yansımaları: Türkiye'de açık ve uzaktan eğitim uygulamaları. Açık Öğretim Uygulamaları ve Araştırmaları Dergisi (AUAd), $6(2), 11-53$.

Canpolat, U. ve Yıldırım, Y. (2021). Ortaokul öğretmenlerinin COVID-19 salgın sürecinde uzaktan eğitim deneyimlerinin incelenmesi. Açıköğretim Uygulamaları ve Araştırmaları Dergisi (AUAd), 7 (1), 74-109.

Creswell, J. W. (2018). Nitel Araştırma Yöntemleri (4. Bask1). (Çev.). Siyasal Kitabevi. Ankara.

Daniel, S. J. (2020). Education and the COVID-19 pandemic. Prospects, 49, 91-96.

Demirören Haber Ajansı. (2020, 18 Nisan). Bingöl'de internete erişim sağlanamayan köyde öğrenciler, EBA'ya bağlanamıyor. https://www.haberler.com/bingol-de-interneteerisim-saglanamayan-koyde-13135409-haberi/Son erişim tarihi:20.02.2021.

Efriana, L. (2021). Problems of online learning during Covid-19 pandemic in EFL classroom and the solution. JELITA: Journal of English Language Teaching and Literature, 2 (1), $38-47$. 
Etikan, İ., Musa, S. A., \& Alkassim, R. S. (2016). Comparison of convenience sampling and purposive sampling. American Journal of Theoretical and Applied Statistics, 5 (1), 1-4.

Erkoca, M.C. (2021) Uzaktan eğitim sürecinde öğrenci ilgisi - bir çalışma. Açıköğretim Uygulamaları ve Araştırmaları Dergisi (AUAd), 7 (1), 148-163.

Fauzi, İ., \& Khusuma, I. H. S. (2021). Teachers' elementary school in online learning of COVID-19 pandemic conditions. Jurnal Iqra' : Kajian Ilmu Pendidikan, 5 (1), 58-70.

Gonzalez, D., \& Louis, R. St. (2018). Online Learning. In J. I. Liontas (Ed.), The TESOL Encyclopedia of English Language Teaching (1st ed.). Retiewed from https://doi.org/10.1002/9781118784235.eelt0423 in 29.06. 2021

Gökbulut, B. (2021). Uzaktan eğitim öğrencilerinin bakış açısıyla uzaktan eğitim ve mobil öğrenme. Eğitim Teknolojisi Kuram ve Uygulamada, 11 (1), 160-177.

Jacobs, G. M., \& Ivone, F. M. (2020). Infusing cooperative learning in distance education. The Electronic Journal for English as a Second Language, 24 (1), 1-15.

Kamal, M., Zubanova, S., Isaeva, A., \& Movchun, V. (2021). Distance learning impact on the English language teaching during COVID-19. Education and Information Technologies. Retiewed from https://link.springer.com/content/pdf/10.1007/s10639-021-10588-y.pdf in 29. 06. 2021.

Kang, W. (2020). What determines citizens' perception of the equality of opportunity?. The Journal of Inequality and Democracy, 3 (2), 22-37.

Karaca, İ., Karaca, N., Karamustafaoğlu, N. ve Özcan, M. (2021). Öğretmenlerin uzaktan eğitimin yararına ilişkin algılarının incelenmesi. Humanistic Perspective, 3 (1), 209-224.

Karadağ, E. ve Yücel, C. (2020). Yeni tip Koronavirüs pandemisi döneminde üniversitelerde uzaktan eğitim: Lisans öğrencileri kapsamında bir değerlendirme çalışması. Yükseköğretim Dergisi, 10 (2), 181-192.

Karakuş, N., Ucuzsatar, N., Karacaoğlu, M. Ö., Esendemir, N. ve Bayraktar, D. (2020). Türkçe öğretmeni adaylarının uzaktan eğitime yönelik görüşleri. RumeliDE Dil ve Edebiyat Araştırmaları Dergisi, 19, 220-241. DOI: 10.29000/rumelide.752297.

Karatepe, F., Küçükgençay, N. ve Peker, B. (2020). Öğretmen adayları senkron uzaktan eğitime nasıl bakıyor? Bir anket çalışması. Journal of Social and Humanities Sciences Research, 7 (53), 1262-1274.

Katrancı, M. ve Uygun, M. (2013). Sınıf öğretmenlerini Türkçe derslerinde teknoloji kullanımına yönelik görüşleri. Adıyaman Üniversitesi Sosyal Bilimler Enstitüsü Dergisi Türkçenin Eğitimi Öğretimi Özel Sayısı, 6 (11), 773-797. 
Kavalc1, K. ve Ünal, S. (2016). Y ve Z kuşaklarının öğrenme stilleri ve tüketici karar verme tarzları açısından karşılaştırılması. Atatürk Üniversitesi Sosyal Bilimler Enstitüsü Dergisi, 20 (3), 1033-1050.

Kavuk, E. ve Demirtaş, H.(2021). COVID-19 pandemisi sürecinde öğretmenlerin uzaktan eğitimde yaşadığı zorluklar. E-International Journal of Pedandragogy(e-ijpa),1 (1), 55 73.

Keskin, M. ve Özer-Kaya, D. (2020). COVID-19 sürecinde öğrencilerin web tabanlı uzaktan eğitime yönelik geri bildirimlerinin değerlendirilmesi. İzmir Katip Çelebi Üniversitesi Sağlık Bilimleri Fakültesi Dergisi, 5 (2), 59-67.

Kırık, A.M. (2014). Uzaktan eğitimin tarihsel gelişimi ve Türkiye'deki durumu. Marmara İletişim Dergisi, 21, 73-94.

Kurnaz, E. ve Serçemeli, M. (2020). Covid-19 pandemi döneminde akademisyenlerin uzaktan eğitim ve muhasebe eğitimine yönelik bakış açıları üzerine bir araştırma. USBAD Uluslararası Sosyal Bilimler Akademi Dergisi 2 (3), 262-288.

Martinez, S. J. R., Camacho, X. G. O., Guillen-Gamez, F. D., \& Agapito, J. B. (2020). Attitudes toward technology among distance education students: Validation of an explanatory model. Online Learning Journal, 24 (2), 59-75.

McAleer, M. (2020). Prevention is better than the cure: Risk management of COVID-19. Journal of Risk and Financial Management, 13 (46), 15-5.

Miles, M, B., \& Huberman, A. M. (1994). Qualitative data analysis: An expanded sourcebook. (2nd ed). Thousand Oaks, CA: Sage.

Özer, M. (2020). Educational policy actions by the Ministry of National Education in the times of COVID-19. Kastamonu Educational Journal, 28 (3), 1124-1129.

Özgül, E. Ceran, D. ve Yıldız, D. (2020). Uzaktan eğitimle yapılan Türkçe dersinin öğretmen görüşlerine göre değerlendirilmesi. Millî Eğitim, 49 (1), 395-412.

Putri, R. S., Purwanto, A., Pramono, R. Asbari, M., Wijayanti, L. M., \& Hyun, C. C. (2020). Impact of the COVID-19 pandemic on online home learning: An explorative study of primary schools in indonesia. International Journal of Advanced Science and Technology, 29 (5), $4809-4818$.

Sarı, H. İ. (2020). Evde kal döneminde uzaktan eğitim: Ölçme ve değerlendirmeyi neden karantinaya almamalıyız?. Uluslararası Eğitim Araştırmacıları Dergisi, 3 (1), 121-128.

Sezgin, S. ve Fırat, M. (2020). Covid-19 pandemisinde uzaktan eğitime geçiş ve dijital uçurum tehlikesi. Açıköğretim Uygulamaları ve Araştırmaları Dergisi (AUAd), 6 (4), 37-54. 
Sirem, Ö. ve Baş, Ö. (2020). Okuma güçlüğü olan ilkokul öğrencilerinin Covid-19 sürecinde uzaktan eğitim deneyimleri. Turkish Studies, 15 (4).

Şendoğan, E. (2021). Foreign language education during COVID-19 pandemic: An evaluation from the perspectives of preparatory class students. Millî Ĕgitim, 49 (1), 1079-1090.

UNICEF. (2019). Primary Education. https://data.unicef.org/topic/education/primaryeducation/. Erişim tarihi: 16.02.2021.

UNICEF. (2020a). How many children and young people have internet access at home? https://data.unicef.org/resources/children-and-young-people-internet-access-at-homeduring-covid19/Son erişim tarihi: 20.02.2021.

UNICEF (2020b). Education and COVID-19. https://data.unicef.org/topic/education/covid-19/ Son erişim tarihi: 15. 01. 2021.

UNICEF. (2020c). Remote learning amid a global pandemic: Insights from MICS6. https://blogs.unicef.org/evidence-for-action/remote-learning-global-pandemic-insightsmics6/Son erişim tarihi. 20.02.2021.

Yaman, H. (2007). Türkçe öğretmeni adaylarının "Öğretim Teknolojileri ve Materyal Geliştirme" dersi bağlamında Türkçe öğretiminde teknoloji kullanımına ilişkin yeterlilik ve algıları. Hasan Al Yücel Eğitim Fakültesi Dergisi, 7, 57-71.

Yıldırım, A. ve Şimşek, H. (2018). Sosyal Bilimlerde Nitel Araştırma Yöntemleri (11.Baskı). Seçkin Yayıncılık. Ankara.

Yıldız, E. (2020). Çevrimiçi öğrenme ortamlarında uzaktan eğitim öğrencilerinin topluluk hissine etki eden faktörlerin incelenmesi. Eğitimde Nitel Araştırmalar Dergisi - Journal of Qualitative Research in Education, 8 (1), 180-205.

Yurtbakan, E. ve Akyıldız, S. (2020). Sınıf öğretmenleri, ilkokul öğrencileri ve ebeveynlerin Covid-19 izolasyon döneminde uygulanan uzaktan eğitim faaliyetleri hakkındaki görüşleri. Turkish Studies, 15 (6), 949-977. 


\section{Yazarlar Hakkında}

\section{Seyfettin BULUT}

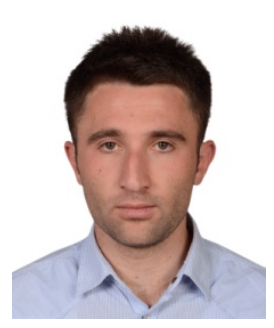

Lisans eğitimini Gazi Üniversitesi Sınıf Öğretmenliği ana bilim dalında tamamlamıştır. Yüksek lisans eğitimini Gazi Üniversitesi, Eğitim Bilimleri Enstitüsü Sınıf Öğretmenliği bilim dalında tamamlamıştır. 2016 yılında Pamukkale Üniversitesi, Eğitim Bilimleri Enstitüsü İlköğretim Bölümünde Doktora eğitimine başlamıştır. Ağırlıklı olarak ilk okuma yazma öğretimi ve Türkçe öğretimi üzerinde çalışmaktadır. 2013 yılında Milli Eğitim Bakanlığına öğretmen olarak atanmıştır. Halen Milli Eğitim Bakanlı̆̆ı'na bağlı olarak Afyonkarahisar ilinde öğretmen olarak çalışmakta ve doktora eğitimini sürdürmektedir.

Posta adresi: Çiçektepe İlkokulu. Dinar / AFYONKARAHISAR

Tel (İş): $\quad$ +90 2723691020

GSM: $\quad$ +905346913143

Eposta: $\quad$ seybulut38@gmail.com

\section{Prof. Dr. Fatma SUSAR KIRMIZI}

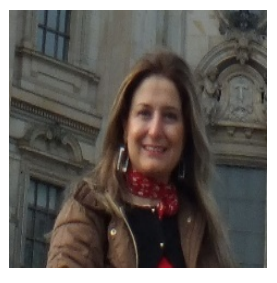

Prof Dr. Fatma SUSAR lisans eğitimini Pamukkale Üniversitesinde Sınıf Öğretmenliği ana bilim dalında tamamlamıştır. Yüksek lisans eğitimini Pamukkale Üniversitesi, Sosyal Bilimler Enstitüsü Sınıf Öğretmenliği Programında; doktora eğitimini de Dokuz Eylül Üniversitesi, Eğitim Bilimleri Enstitüsünde, Sınıf Öğretmenliği Programında gerçekleştirmiştir. 2013 yılında "Sınıf Eğitimi” alanında doçent unvanını almış, 2018 yılında yine aynı alanda profesör olmuştur. Ağırlıklı olarak Türkçe öğretimi, ilk okuma yazma öğretimi, drama, öğretmen yetiştirme çalışmaktadır. Kitap bölümleri, yurt içi ve yurt dışı hakemli dergilerde makaleleri, ulusal ve uluslararası bilimsel toplantılarda bildirileri bulunmaktadır. Halen Pamukkale Üniversitesi Sınıf Öğretmenliği Anabilim Dalında öğretim üyesi olarak görevine devam etmektedir.

Posta adresi: Pamukkale Üniversitesi, Eğitim Fakültesi, Temel Eğitim Bölümü, Sınıf Eğitimi ABD, Kınıklı/DENIZLİ

Tel (İş): $\quad$ +902582961141

GSM: $\quad+905056336072$

Eposta:_fatmakirmizi73@gmail.com 